\title{
Testing the Validity of the Triple Deficit Hypothesis for Nigeria
}

\author{
Rahman Olanrewaju Raji*a \\ ^Canterbury International High School, Lekki-Ajah, Lagos, Nigeria
}

Submitted: May 17, 2019 • Accepted: August 6, 2019

\begin{abstract}
This paper tests the validity of the triple deficit hypothesis in Nigeria by examining the causal relationship among current account deficit, financial account deficit, and fiscal deficit within a five-variate ARDL framework complemented with GMM framework for the period 2008-2017 using quarterly data. The paper obviates the variable omission bias that characterizes most existing studies. The ARDL-bound testing technique confirms that there is the presence of a long-run bi-causal relationship between current account and financial account deficits in Nigeria. The results based on the model and empirical outputs suggest that authorities of this economy must put in place a fully fiscal and monetary discipline policy that should ensure the drastic curtailment of fiscal deficit and create a conducive environment to attract foreign remittances and foreign investment, which would help to generate healthy external balances. In addition, exchange rate stability can promote the export sector and minimize external imbalances through creating critical surpluses in current accounts, including related comprehensive discipline policies that may be pursued, which enable the external sector, financial and fiscal sectors, and monetary sector to perform without creating adverse imbalances in this economy.
\end{abstract}

JEL classification: F32, F41, H62

Keywords: fiscal deficit, current account deficit, financial account deficit, triple deficit hypothesis

\footnotetext{
*Corresponding Author. Email: rahmandole@gmail.com, rahman.raji@rocketmail.com
} 


\section{Introduction}

Keynesian absorption theory and the Mundell-Fleming model argued that a rise in fiscal deficits would increase domestic absorption and imports. The expansion of imports would then lead to the worsening of trade deficits which, in turn, would lead to current account deficits. In addition, as fiscal deficits increase, the level of domestic investments decrease as a result of its crowd-out effects on the economy associated with upward pressure on interest rates. The upward pressure on domestic interest rates leads to an increase in capital inflows and appreciation of the currency. As domestic currency appreciates, it undermines competitiveness and widens the current account deficit. Real exchange appreciation could lead to a sudden drying up of capital flows, causing an abrupt adjustment of the current account and a negative effect on investment that could create major problems for macroeconomic management. Thus, theoretical and empirical arguments establish a strong association between fiscal deficits and current account deficits, called twin deficits.

The conventional Keynesian framework using the Mundell-Fleming model establishes the effects of fiscal balance on capital accounts of balance of payment (BoP) through interest rates and real exchange rate channels. Fiscal deficits trigger real interest rates to rise which, in turn, encourages capital inflows because the domestic financial assets have become more attractive and are associated with higher expected yields; there is a positive net capital inflow, which improves capital accounts. Fiscal deficits also have an influence on capital accounts through the real exchange rate. Tang (2014) submitted that appreciation of the real exchange rate, which is a proxy for the price of the foreign financial assets in the foreign exchange market, has resulted from twin deficits; the cheaper the foreign assets for domestic residents, the more expensive the domestic financial assets for foreign investors. If the exchange rate channel is stronger than the interest rate channel, it implies that capital account deficits in BoP show the presence of third deficits, called triple deficits (fiscal deficit, current account deficit, and capital or financial account deficit). In the balance of payment framework, there is a connection between international trade and international capital flow, meaning that there is a correspondence between net domestic outputs and short-run foreign private flows. This implies that when domestic outputs are greater than domestic absorption representing current account surplus BoP, domestic capital tends to flow out; in contrast, when domestic output is lower than domestic absorption representing current account deficit BoP, foreign capital tends to flow in. Net capital flows (inflows less outflows) respond to the saving-investment differentials between countries and they result in the flow of real resources from countries with a saving-investment surplus to ones with a saving-investment deficit, in reaction to current account imbalances (Obstfeld and Rogoff, 1995).

Empirical studies have been conducted to either validate or refute the triple deficit hypothesis, which is the extension of twin deficits. Akbas and Lebe (2016) determined the 
validity of the triple deficit hypothesis on the G7 countries between 1994 and 2011 and found a bi-directional causality between the saving gap proxy with capital/financial account deficit and budget deficit as well as a bi-directional causality between current account deficit and saving gap. The saving gap was discovered to have an important effect on both the current account and budget deficits. This is consistent with Tang (2014) who tested the triple deficit hypothesis on U.S. data and confirmed that there is a positive relationship between fiscal policy, current account, and capital and financial balances, and that these are cointegrated indicating the presence of a bidirectional causality between current account and fiscal balance as well as the financial position of the United States. Countering these findings, Domenech et al. (2000) tested the triple deficit hypothesis on 18 OECD economies between 1962 and 1994 and found that the cause of the fiscal deficit was not the saving deficits. This is in line with Sen and Kaya (2018) who posited that there was invalidity of the twin or triple deficit hypotheses on six post-communist countries between 1994 and 2012, which agreed with the Ricardian Equivalence Hypothesis and was contrary to conventional approaches implying an absence of the triple deficit hypothesis.

The triple deficit hypothesis debate had produced conflicting and interesting outcomes. Previous research on this debate was widely conducted for countries in developed and developing countries in Europe, Latin America, and Asia, whereas Sub-Saharan Africa and Nigeria's cases have been much less studied. In addition, causality relationships remain ambiguous because of the disparity Granger causality finding, which may be a result of omission of variable bias. This study tends to incorporate other relevant variables, such as interest rate and gross domestic product.

\section{Literature Review}

The persistent increase in fiscal deficits is cited as either a cause or a symptom of economic weaknesses as a result of its adverse effects on macroeconomic variables. One leading key factor receiving considerable attention is the effect of macroeconomic uncertainty on the fiscal deficit, and current and financial account deficits of balance of payment process. Studies like Kuijs (2006), Bachman (1992), Tang (2014), Sen et al. (2014), Sürekçı (2011), Akbas and Lebe (2016), Sen and Kaya (2016), and Shruti et al. (2017) are among the few empirical studies that have tested the validity of extension of the twin deficit hypothesis, called the triple deficit hypothesis. Some of these studies are time-series based, while others are both time-series and cross-section based (panel data analysis).

Regarding the validity of the triple deficit hypothesis on country-specifics, studies based on time series analysis are reviewed as follows: Bachman (1992) tested the triple deficit hypothesis using U.S. data where the findings confirmed that the twin deficits nexus was 
valid in the U.S. economy through the fiscal deficit impacting the economy's trade account deficit; however, the triple deficit hypothesis could not be demonstrated clearly in this study. A similar study was conducted by Tang (2014) using U.S. quarterly data between 1960 and 2013; the study discovered that the triple deficit hypothesis is valid in the United States and there is presence of a causally positive and co-integrating relationship such that the trade balance granger-caused a budget deficit along with the country's financial account position. Kuijs (2006) examined the validity of the triple deficit hypothesis on the Chinese economy in the period of 1980-2005. This study posits that rising saving rates amount to both a budget and trade surplus and that the triple deficit hypothesis applied in reverse to the Chinese economy and was tagged as "Triplet Surpluses".

Sürekçı (2011) and Sen et al. (2014) investigated separately the triple deficit hypothesis on the Turkish economy with different outcomes. Sürekçı (2011) stipulated a causality relationship between budget and trade deficits and insisted on the absence of a causal correlation for saving-investment rate and trade deficit, which shows the inexistence of the triple deficit using quarterly data spanning the years 1987-2007. Sen et al. (2014) employed annual data from 1980 to 2010 in order to find a causal relationship and effect of each on one another. Their findings indicated that the trade deficit and fiscal deficit have a causality to savings deficit, which suggests the validity of the triple deficit hypothesis. In conformity with Sen et al. (2014), Akinci and Yilmaz (2012) disclosed that current account deficits are determined by savings-investment and budget deficits. Their findings showed that both deficits have a positive effect on current account deficit for both the short and long-terms, which validates the triple deficit theory for Turkey over the period 1975-2010. Akbas and Lebe (2016) supported Akinci and Yilmaz (2012), agreeing that a bi-directional causality exists between the trade and fiscal deficit and between the trade deficit and savings gap, revealing that the triple deficit hypothesis was valid for Turkey using annual data for 1960-2012 in the study.

Winner (1993) investigated the parallel between the budget deficit, trade deficits, and savings gap by analyzing the Australian economy. The findings showed that fiscal deficits, as opposed to the savings gap, were due to diverse macroeconomic factors and validated the Ricardian Equivalence Hypothesis (REH). In addition, it was inconclusive that trade deficits were a consequence of fiscal and saving deficits, which implies that the triple deficits were not valid. This contradicts Chowdhury and Saleh (2007), who analyzed the existence of the triple deficit hypothesis using the Autoregressive Distributed Lag (ARDL) approach for Sri Lanka. The existence of triple deficits and budget and savings-investment deficits were presented as a cause of the current account deficits in Sri Lanka for the period 1970-2005.

Given that the panel data provides a time series on each cross-section unit in a group, this study further reviewed studies on panel data. Bolat et al. (2014) assessed the dynamics of the triple deficit theory in 23 European economies using quarterly data between 2002 and 2013 
and with the aid of the panel Granger causality estimation. The study established evidence for the triple deficit hypothesis. In support of Şengönül et al. (2014), Bolat et al. (2014) validated that the triple deficit hypothesis was valid for Poland, Portugal, Spain, and Sweden in their study of European Union countries between 2002 and 2013 using quarterly data for analysis. Contrary to these studies, Domenech et al. (2000) found an absence of a causal relationship between fiscal deficit and saving deficit using panel VAR analysis between 1962 and 1994, establishing that the Ricardian Equivalence Hypothesis was valid in these countries contrary to conventional approaches and concluded that the triple deficit hypothesis was not valid. Furthermore, Sen and Kaya (2018) carried out a study on the validity of the triple deficit hypothesis in six post-communist countries using data between 1994 and 2012 with a bootstrap panel Granger causality estimation, and concluded the invalidity of the twin or triple deficit in their models.

Gruber and Kamin (2007) using panel data analysis attempted to establish the determinants of the trade account deficit in 61 countries for the years 1982-2003. The study concluded that in the sampled countries a growth in savings negatively affects countries that experience a savings gap, consequently resulting in a rise in the trade deficit. The findings contend that the savings-investment gap plays a role in the advent of a trade deficit. In this context, the triple deficit hypothesis was supported by the results. In support of Gruber and Kamin (2007), Özdemir et al. (2014) studied a causal relation between budget deficits, current account deficits, and savings deficits in 17 transition economies from 2003 to 2011 in order to weigh the validity of the triple deficit hypothesis. The outcomes of the study supported evidence for the Ricardian Equivalence Hypothesis, while they showed the invalidity of the triple deficit hypothesis.

Shruti et al. (2017) assessed the triple deficit hypothesis in South Asian countries using panel data analysis between 1985 and 2015. The study reiterates the presence of a long-run relationship between budget balance, current account balance, and private savings gap; that is, there is a positive impact of a budget balance and private savings gap on current account balances and, in addition, a positive causation runs from the savings gap to current account and budget deficits, thus, confirming the triple deficit theory.

In conclusion, there is no concrete consensus among the few existing studies regarding the triple deficit hypothesis because these studies observed contrary opinions in most of the few countries where they had been carried out which might be due to sample periods of their studies. In addition, most studies suffer from omission of the variable bias when testing for causality within the VAR and ARDL models. Specifically, this study incorporates relevant variables as intervening variables that influence both between budget deficit, current account deficit, and financial account deficit of balance of payment. This study tends to overcome this limitation by employing a multivariate ARDL model to examine the causal relationship 
between budget deficit, current account deficit, and financial account deficit of balance of payment.

\section{Theoretical Framework Research}

The theoretical foundation underpinning the connection between fiscal policy and current account balance of payment $(\mathrm{BoP})$ is derived from national account identity through the income-output approach forwarded in the 1960s by Mundell and Fleming; that is, the goods market is in equilibrium when estimated expenditure $(E)$ equals estimated output $(Y)$ per period, i.e., $E=Y$.

Since

$$
\begin{gathered}
\text { estimated income }=C+S+T \\
\text { estimated expenditure }=C+I+G+(X-M)
\end{gathered}
$$

where $C$ is consumption, $S$ is saving, $T$ is tax, $I$ is investment, $G$ is government spending, $X$ is export, $M$ is import. Combining equations (1) and (2), equation (3) is derived as shown below:

$$
C+S+T=C+I+G+X-M
$$

Rearranging equation (3), equation (4) is thus derived as

$$
(S-I)=(G-T)+(X-M)
$$

where $(S-I)$ is saving gap (saving deficit), $(G-T)$ is fiscal deficit, and $(X-M)$ is trade deficit. Therefore, equation (4) displays the triple deficit hypothesis, which expresses imbalances as a result of negative values on both sides of equation (5), which will be even in the case of a triple deficit.

Equation (4) implies that, for a given level of saving rate, the fiscal deficit will crowd out private investment and lead to foreign capital inflows into the economy as a result of excessive government borrowing to finance its spending, which is translated into current account deficit. The crowding out of private investment establishes an increase in the domestic interest rate, which, in turn, amounts to a real exchange rate appreciation and augments capital inflow according to Sakyi and Opoku (2016).

Alternatively, BoP accounting displays the interrelationship between current account and financial account, which is known as capital account. The interrelationship between the two accounts captures responses of the financial sector and real sectors to systematic disturbances and their interaction during the adjustment process. The subsequent balance of payment identity is written as $B o P=C A+F A \equiv 0$, where an alternative interpretation of current or 
financial account transactions could be that $C A=-F A$ or $F A=-C A$. The BoP financial account deficit $(-F A)$ with a floating exchange rate is financed through excess net export $(X>M)$, while the BoP current account deficit is financed through net capital flow or foreign capital inflow. According to national income-expenditure relationships, it reflects that the current account balance is equivalent to the saving-investment or national saving-investment balance $(S-I)$, i.e., $C A=S-I$, and implies that in an open economy, investment can occur at home or abroad using national savings insofar as such investments can promise a good combination of safety and return. Therefore, the saving-investment relationship can be rewritten as $S=I_{d}+I_{f}\left(I_{d}\right.$ is domestic investment and $I_{f}$ is foreign investment), where the foreign investment $I_{f} \equiv C A=-F A$. There is an acquisition of foreign assets $(F A<0)$ along with commensurate transfers of domestic real resources to users abroad $(C A>0)$, so that

$$
(S-I)=C A=-F A
$$

Substituting equation (5) into equation (4), an equilibrium relation of current account can be rewritten as $C A=-F A+B B$ by rearranging this equation, making fiscal policy $(B B)$ the subject of the formula. Thus, it becomes:

$$
-B B=-C A-F A
$$

A triple deficit is established if the three variables $B B, C A$, and $F A$ are co-integrated or moving together. It indicates that a budget deficit in the long run is expected to be offset by the net deficit between current and financial accounts or a combined deficit of current and financial accounts. Therefore, equation (6) is the basis for the empirical model estimation of the study.

\section{Model Estimation}

This study attempts to explore the empirical relationship of the triple deficit hypothesis by applying the autoregressive distributed lag (ARDL) bounds co-integration technique to determine the long-run relationships and short-run dynamics between fiscal, current, and financial account deficits including a control variable (interest rate and gross domestic product), which was developed by Pesaran and Shin (1999) and Pesaran et al. (2001). This estimation technique has some advantages in comparison with other previous and traditional co-integration methods. First, the ARDL does not need all the variables under study to be integrated of the same order and it can be applied when the underlying variables are integrated of order one, order zero, or fractionally. Second, the ARDL test is relatively more efficient in the 
case of small and finite sample data sizes. Lastly, by applying the ARDL technique, we obtain unbiased estimates of the long-run model (Harris and Sollis, 2003). By adopting this technique, the study specifies the empirical ARDL model as:

$$
\begin{array}{r}
\Delta I R_{t}= \\
\phi_{4}+\sum_{i=1}^{n} \beta_{40} \Delta I R_{t-1}+\sum_{i=0}^{n} \beta_{41} \Delta C A_{t-1}+\sum_{i=0}^{n} \beta_{42} \Delta B B_{t-1}+\sum_{i=0}^{n} \beta_{43} \Delta F A_{t-1} \\
+\sum_{i=0}^{n} \beta_{44} \Delta G D P_{t-1}+\beta_{45} \Delta I R_{t-1}+\beta_{46} \Delta C A_{t-1}+\beta_{47} \Delta B B_{t-1}+\beta_{48} \Delta F A_{t-1} \\
+\beta_{49} \Delta G D P_{t-1}+\mu_{t} \\
\Delta G D P_{t}=\phi_{5}+\sum_{i=1}^{n} \beta_{50} \Delta G D P_{t-1}+\sum_{i=0}^{n} \beta_{51} \Delta C A_{t-1}+\sum_{i=0}^{n} \beta_{52} \Delta B B_{t-1}+\sum_{i=0}^{n} \beta_{53} \Delta F A_{t-1} \\
+\sum_{i=0}^{n} \beta_{54} \Delta I R_{t-1}+\beta_{55} \Delta G D P_{t-1}+\beta_{56} \Delta C A_{t-1}+\beta_{57} \Delta B B_{t-1}+\beta_{58} \Delta F A_{t-1} \\
+\beta_{59} \Delta G D P_{t-1}+\mu_{t}
\end{array}
$$

where $B B, C A, F A, I R$, and $G D P$ are fiscal deficit, current account deficit of $B o P$, capital account deficit of BoP, lending rate, and gross domestic product, respectively; $\phi$ and $\beta$ are the parameters of the model; $\Delta$ is the first difference operator; $t$ is the time period; and $\mu_{t}$ is the error term assumed to be identically and independently distributed.

The procedures to carry out the ARDL approach with the co-integration technique include the determination of the long-run relationships among the variables by using the Bounds FTest and the estimation of the coefficients of the long-and short-run relationships by using the error correction model from the ARDL approach. The ARDL bounds-testing procedure for co-integrating relationships follows a non-standard asymptotic F-distribution under the null hypothesis, which maintains that there exists a minimum of one co-integrating vector. Two sets of critical values were constructed by Pesaran et al. (2001) under this null hypothesis. The first set of critical values is constructed under the assumption that variables in the ARDL model are integrated of order zero, $I(0)$.

The second set of critical values is constructed under the assumption that variables in the model are integrated of order one, I(1). We do not reject the null hypothesis of no co-integrating relationships when the F-statistic falls below the lower bound. Similarly, we reject the null hypothesis of no co-integration when the calculated F-statistic is greater than the upper bound. However, the test is inconclusive when the F-statistic falls between the lower and upper bounds. 
The ARDL technique is complementary with the Generalized Method of Moment (GMM) technique in order to check robustness of the estimates. In the GMM estimates, the coefficients of explanatory variables are usually taken to represent a short-term impact. One study showed that several standard estimators, including the instrumental variable method and the ordinary least squares (OLS), are special conditions of the GMM (Çamlica, 2010). The GMM was adopted in order to avoid the problem of endogeneity in explanatory variables. Using this technique, it ensures that the estimators are extremely strong and robust. It allows formulating models and specific estimators without the need for a strong distribution assumption. The stationarity of variables and existence of the required moment conditions for estimation are sufficient using the GMM technique. In addition, it provides a unifying framework for the analysis of many familiar estimators, which include ordinary least squares (OLS) and instrumental variables (IV).

\subsection{The Granger Causality Test Specification}

In order to test the short- and long-run causal linkages between fiscal deficit, current, and financial account deficit, the study specifies approaches in line with previous works such as Tang (2014) and Ali and Kakar (2017). In addition, we agree with Akinlo and Egbetunde (2010) that some macro-variables could have a great impact on one another, i.e., that current account, fiscal balance, and short-term capital inflows can impact each other and that their omission could bias the direction of causality among them. In view of this, we included some control variables: gross domestic product (GDP) and interest rate. GDP is included to control the cyclical components of the current account and capital account of BoP as well as fiscal policy while lending rate is to show the transmission of the fiscal policy, current account, and capital of BoP and it is related to monetary policy actions because they have different responses to cyclical movement.

In order to examine the short- and long-run causal linkages between current account deficit, capital account deficit, interest rate, and gross domestic product, the study specifies the model below:

$$
\begin{aligned}
\Delta B B_{t}= & \gamma_{1}+\sum_{i=1}^{n} \alpha_{10} \Delta B B_{t-1}+\sum_{i=0}^{n} \alpha_{11} \Delta C A_{t-1}+\sum_{i=0}^{n} \alpha_{12} \Delta F A_{t-1} \\
& +\sum_{i=0}^{n} \alpha_{13} \Delta I R_{t-1}+\sum_{i=0}^{n} \alpha_{14} \Delta G D P_{t-1}+\beta_{15} E C M_{t-1}+\mu_{t}
\end{aligned}
$$




$$
\begin{aligned}
\Delta C A_{t}= & \gamma_{2}+\sum_{i=1}^{n} \alpha_{20} \Delta B B_{t-1}+\sum_{i=0}^{n} \alpha_{22} \Delta F A_{t-1}+\sum_{i=0}^{n} \alpha_{23} \Delta I R_{t-1} \\
& +\sum_{i=0}^{n} \alpha_{24} \Delta G D P_{t-1}+\beta_{29} E C M_{t-1}+\mu_{t} \\
\Delta F A_{t}= & \gamma_{3}+\sum_{i=1}^{n} \alpha_{30} \Delta F A_{t-1}+\sum_{i=0}^{n} \alpha_{31} \Delta C A_{t-1}+\sum_{i=0}^{n} \alpha_{32} \Delta B B_{t-1} \\
& +\sum_{i=0}^{n} \alpha_{33} \Delta I R_{t-1}+\sum_{i=0}^{n} \alpha_{34} \Delta G D P_{t-1}+\beta_{39} E C M_{t-1}+\mu_{t} \\
\Delta I R_{t}= & \gamma_{4}+\sum_{i=1}^{n} \alpha_{40} \Delta I R_{t-1}+\sum_{i=0}^{n} \alpha_{41} \Delta C A_{t-1}+\sum_{i=0}^{n} \alpha_{42} \Delta B B_{t-1} \\
+ & \sum_{i=0}^{n} \alpha_{43} \Delta F A_{t-1}+\sum_{i=0}^{n} \alpha_{44} \Delta G D P_{t-1}+\beta_{49} E C M_{t-1}+\mu_{t} \\
& +\sum_{i=0}^{n} \alpha_{53} \Delta F A_{t-1}+\sum_{i=0}^{n} \alpha_{54} \Delta I R_{t-1}+\beta_{59} E C M_{t-1}+\mu_{t} \\
\Delta G D P_{t}= & \gamma_{5}+\sum_{i=1}^{n} \alpha_{50} \Delta G D P_{t-1}+\sum_{i=0}^{n} \alpha_{51} \Delta C A_{t-1}+\sum_{52}^{n} \alpha_{t-1} \Delta B_{t-1}
\end{aligned}
$$

where $E C M_{t-1}$ is the error correction term and $\mu_{t}$ is the mutually uncorrelated white noise residual. The coefficient of the $E C M$ variable contains information about whether the past values of variables affect the current values of the variables under study. The size and statistical significance of the coefficient of the error correction term in each ECM model measure the tendencies of each variable to return to the equilibrium.

In order to examine the short- and long-run causal linkages between current account deficit, fiscal deficit, and financial account deficit following the previous works, evidence suggests that once there is a long-run relationship between the variables, in this case current account deficit, fiscal deficit, financial account deficit, and control variables, then there is a case for causality in one or more directions (Narayan and Smyth, 2005). Nonetheless, we could only establish the direction of the long-run causality between the variables by conducting a test of statistical significance (a z-test) on the lagged error-correction term 
in each equation. The direction of the short-run causal relationships between the variables could also be established by conducting a joint test of statistical significance (a P-value) of the explanatory variables in each of the equations (see Oh and Lee, 2004; Narayan and Smyth, 2005). All the variables are at the level except gross domestic product and lending rate, which were in their logarithm form to avoid measurement error and to provide reliable estimates.

\subsection{Data Sources}

The study is carried out using quarterly data over the 2008Q1 to 2017Q4 periods. These periods are set because, prior to 2008, some of the data were reported annually and, also, checked for how sensitive they were for a specific regime. The data used are all sourced from the Central Bank of Nigeria database, specifically, its 2018Q2 quarterly statistical bulletin compilation such as fiscal balance (defined as fiscal surplus/deficit as percentage of GDP), current account balance (defined as current account balance as percentage of GDP), financial account balance (defined as capital and financial account balance as percentage of GDP), gross domestic product, and lending. The monthly fiscal deficit/surplus and lending rate data were converted into quarterly data using an e-view package.

\section{Empirical Results and Discussion of Results}

\subsection{Descriptive Statistics of Data Series}

Table 1 presents the summary statistics of the sample data on the variables used for the analysis. The descriptive statistics show that the mean value of the fiscal deficit over the period is -1.664 with a median value of -1.714 . The maximum and minimum values are 0.849 and -3.752 , respectively. The mean values of the current account deficit and financial account deficit over the period are 3.877 and 0.312 , respectively, with median values of 3.250 and 0.145 , respectively. The maximum and minimum values for the current account are 20.870 and 5.320, respectively, whereas the financial account of maximum value and minimum value are 20.870 and -17.950 , respectively. There is an indication that current account deficit, financial account deficit, and fiscal deficit over the period have been characterized by a marked disparity, implying that these variables were high in some years, whereas they were abysmally lower than the observed average in other years. With regard to dispersion, it is confirmed by the relatively high standard deviation values of 5.825 and 7.519 for current account and financial account, respectively, while fiscal balance has a low standard deviation value. Apparently, current account and financial account have been generally increasing and unstable in the country. The lending rate has a mean value of 2.822 and a median 
value of 2.819, with a low value of standard deviation. Its corresponding maximum and minimum values are 2.910 and 2.737, respectively. The GDP has a mean value of 31.803 and a median value of 31.970 , with a low level of dispersion. Its maximum and minimum values are 32.375 and 30.837 , respectively. The means and medians of all the variables lie within the maximum and minimum values, implying that the variables had a high tendency to be normally distributed.

Skewness is a measure of asymmetry of the distribution of the series around its mean. Regarding the skewness of the variable, the rule of thumb may be arbitrary; but the general threshold is 1 . Since all the variables lie within 1.0 and -1.0, the skewness is not substantial and it can be said that all the distributions of the variables are symmetrical. The Kurtosis statistic measures the peakedness or flatness of the distribution of the series. A Gaussian distribution is expected to have kurtosis of 3.0 (Wooldridge, 2013); since all the variables lie within the range of 3 , it implies that all the variables had a high tendency to be normally distributed. Finally, the Jarque-Bera test revealed that the variables are not normally distributed except for the financial account with a p-value of 0.424 , which means that we reject $\mathrm{HO}$ indicating that the hypothesis of normality in the distribution cannot be accepted. This implies that the data series may have endogeneity issues. This, therefore, necessitates the adoption of a GMM estimator to complement an ARDL which is capable of controlling the joint endogeneity effect of most of the explanatory variables with the current account deficit and fiscal deficit.

\subsection{Stationarity Test}

Although ARDL does not require a data pretesting, this study's author decided to determine the order of integration of all the data before estimation of the data using ARDL. The table below shows the results of the Augmented Dickey-Fuller (ADF) unit root tests for the order of integration of the variables under investigation.

The results of the Augmented Dickey-Fuller (ADF) unit root test conducted to determine the stationarity properties of selected variables by taking into account the intercept without the trend properties, the results obtained showed that, with the exception of fiscal deficit and gross domestic product, all other variables are characterized by the unit root at level, whereas all the variables revealed evidence of stationarity at first difference, mostly at a 5 percent significance level. In conclusion, all the variables revealed evidence of stationarity at first difference at a mostly 5 percent significance level in the ADF test; therefore, all the variables are integrated of order 1, which lend support to the use of ARDL. 


\subsection{Results of the ARDL Bounds Test for Co-Integration}

Since the variables were found to be $I(1)$ processes, there is a tendency that candidate variables would move together in the long run when they drift apart in the short run. Our study employed the ARDL bounds-testing procedure to examine the potential long-run relationships between these variables. Following Pesaran et al. (2001), an F-test on equations (7) to (11) would be sufficient to examine whether or not there were co-integrating relationships between the candidate variables. The study performed an F-test on equations (7) to (11) and reported the results in Table 3.

In equation (7), the fiscal deficit equation shows that the F-statistic, 4.22, calculated for equation (1) was greater than the upper bound value at 5 percent and 10 percent levels of significance. The null hypothesis of no co-integration was rejected, which implies that there is a long-run relationship between $F D, C A, F A, I R$, and $G D P$.

In equation (8), the current account deficit equation, the F-statistic, 4.68, was also greater than the upper bound value at the 5 percent and 10 percent levels of significance. This implies that the null hypothesis of no co-integration was rejected. Therefore, $C A, F A, F D, I R$, and $G D P$ were said to be co-integrated, and the co-integrating vector was explaining $C A$.

In equation (9), the financial account deficit equation, the F-statistic, 7.24, was also greater than the upper bound value at the 1 percent, 5 percent, and 10 percent levels of significance. This implies that the null hypothesis of no co-integration was rejected. Therefore, $F A, C A, F D, I R$, and $G D P$ were said to be co-integrated, and the co-integrating vector was explaining $F A$. In equation (10), the lending rate equation, the F-statistic, 9.83, was also greater than the upper bound value at the 1 percent, 5 percent, and 10 percent levels of significance. This implies that the null hypothesis of no co-integration was rejected. Therefore, $I R, F A, C A, F D$, and $G D P$ were said to be co-integrated, and the co-integrating vector was explaining $I R$.

The results show that the F-statistic, 2.28, calculated for equation (11) was less than the lower bound value at the 1 percent, 5 percent, and 10 percent levels of significance. Following Bahmani-Oskooee and Brooks (1999), the study verifies the long-run error correction model of equation (11) by estimating the long-run error correction model of equation (11). The results show that the error correction term was negative and significant at a 5 percent level of significance. So, for equation (11), the conclusion was that GDP was a co-integrating vector. Thus, the null hypothesis of level effects or co-integration was rejected in that case. In conclusion, the findings disclosed the existence of a long-run co-integrating relationship in the empirical evidence of the extension of twin deficits (so called triple deficits) in Nigeria between 2008 and 2017. 


\subsection{Results of the Granger Causality Test}

After establishing co-integrating relationships between budget deficit, current account deficit, financial account deficit, and control variables (exchange rate and interest rate), we next tested the direction of the causal relationships between these variables, especially key variables of interests. The study conducted short-run causality tests using p-values and test for the significance of the lagged error-correction terms, $E C M_{t-1}$, in order to establish the long-run causality between the explanatory variables and the dependent variable, using the t-test error correction model stipulated above.

The long-run causal flow between current account deficit and fiscal deficit indicates a bi-directional causality, which was supported by the negativity and significance of the error correction terms of equations, the current account deficit, and fiscal deficit equations with a 1 percent significance level of the t-test. It implies that there is the presence of twin deficits in the case of Nigeria in the long term. In addition, a bi-directional long-run causal relationship exists between financial account deficit and fiscal deficit supported with negativity and significance of the error correction term of the equations at a 1 percent significance level of the t-test. Surprisingly, there is an absence of a causal relationship between current account deficit and fiscal deficit, and, likewise, between financial account deficit and fiscal deficit in the short run. Evidence of a bi-directional causality relationship is reported between the current account and financial account deficits in both short-term and long-term causal relationships. The current account deficit equation reveals a negative short-run causal flow from financial account deficit to current account deficit with a p-value of 0.044 associated with the joint statistical test of significance of the financial account deficit at a 1 percent significance level. In case of reverse causality, the financial account deficit equation shows evidence of a positive short-term causal flow from the current account deficit to financial account deficit with a p-value of 0.029 associated with the joint statistical test of significance of current account deficit at a 5 percent significance level. There is evidence of a bi-directional causality in the long-run causal flow between the current account deficit and financial account deficit, which is supported by the negativity and significance of the error correction terms of both equations. The current account and financial account deficit equations are under the 1 percent significance level of the t-test.

Other results show that there was a distinct unidirectional short- and long-run causal flow from fiscal deficit to gross domestic product, and from gross domestic product to lending rate, which was supported by the p-value associated with the joint statistical test of significance of fiscal deficit and gross domestic product while the coefficients of the error-correction terms were negative and statistically significant.

Furthermore, bi-directional short- and long-run causal relationships exist between fiscal deficit and lending rate, current account deficit and lending rate, gross domestic product and 
current account deficit, and, likewise, financial account deficit and gross domestic product. These findings were supported by the p-value associated with the joint statistical test of significance of their respective equations and the coefficient of the error-correction terms, which were negative and statistically significant.

The results of the GMM estimates are reported in Table 5 and show the estimated tstatistic and p-value of the explanatory variables, which are usually taken to represent a short-term impact. The GMM estimates lead to an almost identical conclusion with the ADRL estimates.

However, these statistics (F-statistic and t-statistic of the lagged ECM) suggest that all the five series $(B B, F A, C A, I R$, and $G D P)$ are co-integrated in the long run and; hence, there is strong evidence in support of the triple deficit hypothesis in the case of Nigeria. In addition, the triple deficit hypothesis pertaining to fiscal deficit $(F D)$, current account deficit $(C A)$, and financial account deficit $(F A)$ has also been validated in the long run through the Granger causality using F-statistic and t-statistic of the lagged ECM, whereas the existence of the triple deficit hypothesis is tentatively not held in the short run in the case of Nigeria.

\section{Concluding Remarks}

This paper studies the relationship between fiscal deficit, current account deficit, and financial account deficit and tests the extension of the twin deficit hypothesis called the "triple deficit hypothesis" in Nigeria using quarterly time-series data for the sample periods of 2008Q1 to 2017Q4 by means of ARDL co-integration and Granger causality techniques.

The findings observe a bi-directional causality relationship between the candidate variables of interest (fiscal deficit, current account deficit, and financial account deficit) in the long run. It implies that the outcome of the findings is in support of the Keynesian proposition of a long-run relationship between the twin deficits, which is valid for the Nigerian economy due to a co-integration test demonstrating the existence of a long-run equilibrium relationship between the fiscal deficit and current account deficit. This result agrees with the one earlier obtained by Egwaikhide et al. (2002) and Omoniyi et al. (2012), but it contradicts the result found in Onafowokan and Owoye (2006). In addition, the short-run causal relationship of the outcome of the study rejects an existence of a causal relationship running between fiscal deficits and current account deficits; this contradicts the Mundell-Fleming Model, which states the direction of causality running from fiscal deficit to current account deficit.

However, there are policy implications in these findings: a negative and bi-directional causal relation between current account and financial account deficits indicates that the two accounts offset each other, in such a way that they promote a balance of payment equilibrium. 
More importantly, authorities of this economy must put in place a fully disciplined fiscal policy that should ensure the drastic curtailment of fiscal deficits and, at the same time, create a conducive environment to attract foreign remittances and foreign investment, which would help to generate healthy external balances. In addition, exchange rate stability can promote the exports sector, minimizing external imbalances through creating critical surpluses in current accounts and including related comprehensive discipline policies that may be pursued, which would enable the external, financial, fiscal, and monetary sectors to perform without creating adverse imbalances in this economy.

Our findings support the existence of a twin divergence relationship (twin deficit) in Nigeria. This implies that fiscal policy needs to be treated as a fully controlled policy variable (Biswas et al., 1992). Hence, budget cuts are needed, which would tend to reduce the current chronic account deficits by increasing national savings through reducing the budget/fiscal deficit and increasing private savings in these economies. With this fully controlled policy variable, there is a possibility of achieving a trimmed down current account deficit.

\section{References}

Akbas, Y. E. and Lebe, F. (2016). Current Account Deficit, Budget Deficit and Saving Gap: Is the Twin or Triplet Deficit Hypothesis Valid in G7 Countries? Prague Economic Papers, 2016(3):271-286.

Akinci, M. and Yilmaz, O. (2012). Validity of the Triple Deficit Hypothesis in Turkey Bounds Test Approach. Istanbul Stock Exchange Review, 13(50):1-28.

Akinlo, A. and Egbetunde (2010). Financial Development and Economic Growth: The Experienceof 10 Su-Saharan African Countries Revisited. The Review of Finance and Banking.

Ali, A. and Kakar, A. (2017). Probing the evidence of triple deficit hypothesis in Pakistan. International Journal of Social Sciences, Humanities and Education, 1(1).

Bachman, B. (1992). Current Account Deficit Unrelated to Budget Surplus. Technical report, National Centre for Policy Analysis.

Biswas, B., Tribedy, G., and Saunders, P. (1992). Further Analysis of the Twin Deficits. Contemporary Policy Issues, pages 104-107.

Bolat, S., Degirmen, S., and Sengonul, A. (2014). Does triple deficits have (Un) stable causality for the EU members? Evidence from bootstrap corrected causality tests. Procedia Economics and Finance, 16:603-612. 
Çamlıca, F. (2010). Yeni Keynesyen Bir Bakış Açısıyla Türkiye'nin Enflasyon Dinamikleri Yönünden Yapısal Analizi. Uzmanlık Yeterlilik Tezi, Türkiye Cumhuriyet Merkez Bankası, Ocak.

Chowdhury, K. and Saleh, A. S. (2007). Testing the Keynesian proposition of twin deficits in the presence of trade liberalisation : evidence from Sri Lanka. Faculty of Business Economics Working Papers, pages 2-35.

Şengönül, A., Bolat, S., and Değirmen, S. (2014). Does Triple Deficits Have (Un)Stable Causality for the EU Members? Evidence from Bootstrap-Corrected Causality Tests. Procedia Economics and Finance, 16:603-6012.

Domenech, R., Taguas, D., and Varela, J. (2000). The Effects of Budget Deficit on National Saving in the OECD. Economics Letters, 69(3):377-383.

Egwaikhide, F. O., Ayodele, S. O., Oyeranti, O. A., and Tchokote, J. (2002). Causality between Budget Deficit and the Current Account Balance in African Countries. West African Journal of Monetary and Economic Integration, 2(2):10-41.

Gruber, J. W. and Kamin, S. B. (2007). Explaining the global pattern of current account imbalances. Journal of International Money and Finance, 26(4):500-522.

Harris, R. and Sollis, R. (2003). Applied Time Series Modelling and Forecasting. Wiley, Applications.

Kuijs, L. (2006). How Will China's Saving-Investment Balance Evolve? Working paper no. 3958, World Bank Policy Research.

Narayan, P. K. and Smyth, R. (2005). The Residential Demand for Electricity in Australia: An Application of the Bounds Testing Approach to Cointegration. Energy Policy, 33:467474.

Obstfeld, M. and Rogoff, K. (1995). The Intertemporal Approach to the Current Account, in: Handbook of International Economics, Volume 3, Chapter 33. In Groomsman, G. and Rogoff, K., editors, Handbook of International Economics. North-Holland, Amsterdam.

Oh, W. and Lee, K. (2004). Energy Consumption and Economic Growth in Korea: Testing the Causality Relation. Journal of Policy Modelling, 26(8-9):973-981.

Omoniyi, O. S., Olasunkanmi, O. I., and Babatunde, O. A. (2012). Empirical Analysis of Twins' Deficits in Nigeria. International Journal of Management and Business Studies, $2(3): 38-41$. 
Onafowokan, O. A. and Owoye, O. (2006). An Empirical Investigation of Budget and Trade Deficits: The Case of Nigeria. Journal of Developing Areas, 39(2):153-174.

Özdemir, D., Buzdağlı, O., Emsen, O., and Çelik, A. (2014). Causal Relationship between Budget Deficit and Current Account Deficit. In International Conference on Eurasian Economies.

Pesaran, M. H. and Shin, Y. (1999). An Autoregressive Distributed Lag modeling approach to Co- integration analysis. In Strom, S., editor, Econometrics and economic theory in the 20th century: The Ranger Frisch centennial symposium. Cambridge University Press.

Pesaran, M. H., Shin, Y., and Smith, R. C. (2001). Bounds Testing Approaches to the Analysis of Level Relationships. Journal of Applied Economics, 16:289-326.

Sakyi, D. and Opoku, O. (2016). The twin deficits hypothesis in developing countries: Empirical evidence for Ghana (Technical No. S-33201-GHA-1). International Growth Centre.

Sen, A., Senturk, M., Sancar, C., and Akbas, Y. E. (2014). Empirical Findings on Triplet Deficits Hypothesis: The Case of Turkey. Journal of Economic Cooperation and Development, 35:81-102.

Sen, H. and Kaya, A. (2016). Are the Twin or Triple Deficits Hypotheses Applicable to PostCommunist Countries? Technical report, BOFIT Discussion Papers, Bank of Finland.

Sen, H. and Kaya, A. (2018). Are the Twin or Triple Deficits Hypotheses Applicable to Post-Communist Countries? Panoeconomicus, pages 1-29.

Shruti, S., Giri, A. K., and Mohapatra, G. (2017). Assessing the Triple Deficit Hypothesis for Major South Asian Countries: A Panel Data Analysis. International Journal of Economics and Financial Issues, 7(4):292-299.

Sürekçı, D. (2011). Türkiye'de ÜÃß̃̃ (Ez Açılar Olgusunun Analizi: Dinamik Bir Yaklaşım. Yönetim ve Ekonomi, 18:51 - 69 .

Tang, T. C. (2014). Fiscal Deficit, Trade Deficit, and Financial Account Deficit: Triple Deficits Hypothesis with the U.S. Experience. Technical report, Monash University, Business and Economics, Discussion Paper.

Winner, L. E. (1993). The Relationship of the Current Account Balance and the Budget Balance. The American Economist, 37(2):78-84. 
Table 1: Descriptive Statistics

\begin{tabular}{lccccc}
\hline & $\begin{array}{c}\text { Current } \\
\text { Account }\end{array}$ & $\begin{array}{c}\text { Financial } \\
\text { Account }\end{array}$ & $\begin{array}{c}\text { Fiscal } \\
\text { Balance }\end{array}$ & $\begin{array}{c}\text { Lending } \\
\text { Rate }\end{array}$ & GDP \\
\hline Mean & 3.877500 & 0.312000 & -1.664000 & 2.822200 & 31.80304 \\
Median & 3.250000 & 0.145000 & -1.714844 & 2.819815 & 31.97073 \\
Maximum & 20.87000 & 20.87000 & 0.849375 & 2.910174 & 32.37595 \\
Minimum & -5.320000 & -17.95000 & -3.753438 & 2.737609 & 30.83782 \\
Std. Dev. & 5.825233 & 7.519574 & 0.833665 & 0.033627 & 0.527179 \\
Skewness & 1.508383 & 0.023932 & 0.265486 & 0.560367 & -0.961089 \\
Kurtosis & 5.223504 & 4.012884 & 4.781443 & 4.181100 & 2.528093 \\
Jarque-Bera & 23.40807 & 1.713709 & 5.759115 & 4.418402 & 6.529104 \\
Probability & 0.000008 & 0.424495 & 0.056160 & 0.109788 & 0.038214 \\
Observations & 40 & 40 & 40 & 40 & 40 \\
\hline
\end{tabular}

Table 2: Unit Root Test Results

\begin{tabular}{lll}
\hline \multirow{2}{*}{ Variables } & \multicolumn{2}{c}{ ADF Test } \\
\cline { 2 - 3 } & Level & $1^{\text {st }}$ Difference \\
\hline Current Account Deficit & $-3.96^{*}$ & $-8.29^{*}$ \\
Capital Account Deficit & $-4.94^{*}$ & $-7.33^{*}$ \\
Fiscal Deficit & -2.07 & $-2.93^{* * *}$ \\
Lending Rate & $-3.32^{* *}$ & $-3.77^{* *}$ \\
Gross Domestic Product & -0.13 & $-3.05^{* *}$ \\
\hline
\end{tabular}

Note: Significance level: $1 \%(-3.62)(*), 5 \%(-2.94)(* *)$, and $10 \%(-2.61)(* * *)$ 
Table 3: ARDL Bounds Test for Co-Integration

\begin{tabular}{ccc}
\hline Dependent variable & Function & F-statistic \\
\hline BB & $B B(C A, F A, I R, G D P)$ & $4.22^{* *}$ \\
CA & $C A(F A, B B, I R, G D P)$ & $4.68^{* *}$ \\
FA & $F A(C A, B B, I R, G D P)$ & $7.24^{*}$ \\
IR & $I R(C A, F A, B B, G D P)$ & $9.83^{*}$ \\
GDP & $G D P(C A, F A, B B, I R)$ & 2.28 \\
\hline
\end{tabular}

Critical Value Bound

\begin{tabular}{cccccc}
\hline \multicolumn{2}{c}{$1 \%$} & \multicolumn{2}{c}{$5 \%$} & \multicolumn{2}{c}{$10 \%$} \\
$I(\mathrm{~L})$ & $I(\mathrm{U})$ & $I(\mathrm{~L})$ & $I(\mathrm{U})$ & $I(\mathrm{~L})$ & $I(\mathrm{U})$ \\
3.74 & 5.06 & 2.86 & 4.01 & 2.45 & 3.52 \\
\hline
\end{tabular}

Note: $*$ and $* *$ denotes significance at a $1 \%$ and $5 \%$ significance level.

Table 4: Granger Causality between Current Account Deficit, Capital Account Deficit, and Fiscal Deficit

\begin{tabular}{lcccccc}
\hline Variable & $B B$ & $C A$ & t-statistics $(P$-value $)$ & $I R$ & $G D P$ & $\begin{array}{c}E C M_{t-1} \\
\text { Coefficient } \\
\text { t-statistic })\end{array}$ \\
\hline$B B$ & - & $-1.09(0.285)$ & $-0.91(0.369)$ & $-2.17(0.038)^{* *}$ & $-0.38(0.699)$ & $-0.19(-3.473)^{*}$ \\
$C A$ & $-0.60(0.551)$ & - & $-2.11(0.044)^{* *}$ & $-3.02(0.005)^{*}$ & $-4.57(0.000)^{*}$ & $-1.01(-6.261)^{*}$ \\
$F A$ & $-0.19(0.853)$ & $-2.29(0.029)^{* *}$ & - & $-0.65(0.516)$ & $-1.97(0.058)^{* *}$ & $-0.90(-5.680)^{*}$ \\
$I R$ & $-1.49(0.145)^{* * *}$ & $-2.01(0.054)^{* *}$ & $-0.60(0.550)$ & - & $-3.41(0.002)^{*}$ & $-0.29(-3.181)^{* *}$ \\
$G D P$ & $-1.53(0.136)^{* * *}$ & $-2.67(0.012)^{* *}$ & $-3.65(0.001)^{*}$ & $-1.08(0.289)$ & - & $-0.20(-2.993)^{* *}$ \\
\hline
\end{tabular}

Note: ${ }^{*}, * *$, and $* * *$ imply statistical significance at the $1 \%, 5 \%$, and $10 \%$ significance levels, respectively. 
Table 5: GMM Results - t-statistic (p-value)

\begin{tabular}{lccccc}
\hline & $B B$ & $C A$ & $F A$ & $I R$ & $G D P$ \\
\hline$B B$ & - & $-0.71(0.485)$ & $-0.37(0.706)$ & $-3.93(0.004)^{* *}$ & $-2.31(0.027)^{* *}$ \\
$C A$ & $-1.28(0.211)$ & - & $-2.83(0.008)^{* *}$ & $-5.87(0.000)^{*}$ & $-9.61(0.000)^{*}$ \\
$F A$ & $-1.10(0.279)$ & $-5.09(0.000)^{*}$ & - & $-1.49(0.149)$ & $-4.21(0.000)^{*}$ \\
$I R$ & $-2.71(0.011)^{* * *}$ & $-4.57(0.001)^{*}$ & $-0.35(0.727)$ & - & $-7.44(0.000)^{*}$ \\
$G D P$ & $-2.72(0.011)^{* * *}$ & $-7.07(0.000)^{*}$ & $-1.89(0.068)^{* * *}$ & $-6.52(0.000)^{*}$ & - \\
$R^{2}$ & & & & & \\
Instrument & 0.27 & 0.61 & 0.18 & 0.54 & 0.75 \\
Rank & 10 & 10 & 10 & & 10 \\
J-statistic & 6.5 & 1.5 & 2.6 & 3.3 & 6.5 \\
\hline
\end{tabular}

Note: $* * *$, and $* * *$ imply a statistical significance at the $1 \%, 5 \%$, and $10 \%$ significance levels, respectively. 